\title{
PENGARUH PRESTASI BELAJAR DAN SELF REGULATED LEARNING TERHADAP TINGKAT STRES SISWA FULL DAY SCHOOL DI SMK KESEHATAN UTAMA INSANI TAHUN 2020
}

Bambang Mardisentosa'; Ida Faridah'; Bella Aprilia Pertiwi $^{3}$

1Universitas Islam Syekh

Yusuf Tangerang,

Indonesia; ${ }^{2}$ Dosen

Keperawatan, STIKes

YATSI Tangerang

email: bmardi@unis.ac.id

\section{ABSTRACT}

The Full Day School system has been approved through the Ministry of Education number 23 2017. The implementation of the Full Day School system makes students stressed and stressed, because students are always asked to be active in every subject and homework given so that their rest time is reduced. Objective: To find out the effect of Self Regulated Learning achievement on the stress level of Full Day School students at 2020 Main Health Insani Vocational School. Research Method: In this study using a comparative causal or cross sectional approach using normality test, multicollinearity, heteroscedasticity, multiple regression, T test and $\mathrm{F}$ test. The sample technique used was simple random sampling of 70 respondents. Research Results: Based on the T test, learning achievement has no effect on the stress level of full day school students, Self Regulated Learning has an effect on the stress level of full day school students. Based on the research results of the F test of learning achievement and Self Regulated Learning affect the stress level of full day school students with the results of the F table 12.190 with a value of 0.000 Sig. Conclusion: The results of the study there is the effect of Self Regulated Learning on the stress level of full day school students.

Keywords: Plagiarism, Law, Criminal Act, Education, College.

\section{A. PENDAHULUAN}

SRL dapat didefinisikan dengan cara berikut: "Ini adalah proses aktif dan konstruktif yang diatur oleh peserta didik tujuan pembelajaran mereka dan kemudian mencoba untuk memantau, mengatur, dan mengendalikan kognisi, motivasi, dan perilaku, dipandu dan dibatasi oleh tujuan mereka dan fitur kontekstual di lingkungan. Jadi, SRL mengintegrasikan dimensi kognitif, afektif-motivasi, dan perilaku, yang semuanya adalah berhubungan positif dengan tingkat pembelajaran dan hasil akademis pada masa remaja, selain sebagai dasar kompetensi untuk dikembangkan di sekolah menengah. (Fuentes dkk, 2019).

Sekolah seharian penuh (Full day school) terdiri dari 3 kata yaitu penuh (full), Hari (Day) dan sekolah (school) yang atinya kegiatan sehari penuh disekolah disebut full day school. Kemendiknas mengadakan satunan pendidikan sesuai dengan kurikulum kemenag yaitu bentuk sekolah dengan sistem Full day school. Proses belajar mengajar mulai diberlakukan dari pukul 06.40 pagi sampai I5.40 sore, melalui peraturan mentri pendidikan nomor 23 tahun 2017 sistem tersebut telah disahkan (Soapatty, 2014).

Pelaksanaan sistem Full Day School membuat siswa menjadi tertekan dan stres, karena siswa selalu ditutut untuk aktif pada setiap mata pelajaran dan pekerjaan rumah yang diberikan sehingga waktu istirahat mereka menjadi 
berkurang. Berdasarkan fenomena diatas peneliti tertarik mengadakan penelitian tentang Pengaruh Prestasi belajar Dan Self Regulated Learning Terhadap Tingkat Stres Siswa Full Day School Di SMK Kesehatan Utama lnsani Tahun 2020.

\section{B. METODE PENELITIAN}

Penelitian ini menggunakan metode kausal komparatif dengan pendekatan kuantitatif. Penelitian ini menggunakan pendekatan cross sectional. Penelitian ini dilaksanakan pada bulan Juni tahun 2020. Populasi dalam penelitian ini adalah siswa dari kelas X, XI, dan XII di SMK Kesehatan Utama Insani dengan jumlah populasi

236 siswa. Sampel pada penelitian ini melibatkan 70 responden. Teknik sampel yang digunakan pada penelitian ini yaitu simple random sampling. Alat pengumpulan data menggunakan kuesioner dan rata-rata nilai raport siswa.

\section{HASIL PENELITIAN DAN PEMBAHASAN}

\section{Karakteristik Responden}

Distribusi Frekuensi Berdasarkan Usia Pada Siswa Di SMK Kesehatan Utama Insani Tahun 2020.

\begin{tabular}{ccc}
\hline Usia & $\begin{array}{c}\text { Jumlah } \\
\text { (n) }\end{array}$ & $\begin{array}{c}\text { Presentase } \\
\mathbf{( \% )}\end{array}$ \\
\hline 16 Tahun & 16 & $22,9 \%$ \\
\hline 17 Tahun & 28 & $40,0 \%$ \\
\hline 18 Tahun & 17 & $24,3 \%$ \\
\hline 19 Tahun & 9 & $12,9 \%$ \\
\hline Total & 70 & $100 \%$
\end{tabular}

Tabel diatas dapat disimpulkan bahwa sebagian besar responden berusia 17 tahun $(40,0 \%)$.

2. Analisa Univariat

Prestasi Belajar

\begin{tabular}{ccc}
\hline $\begin{array}{c}\text { Karakteristi } \\
\mathbf{k}\end{array}$ & Jumlah & Presentase \\
\hline Rendah & 28 & $40,0 \%$ \\
\hline Tinggi & 42 & $60,0 \%$ \\
\hline
\end{tabular}

Dapat diketahui bahwa distribusi frekuensi prestasi belajar yang tertinggi sebanyak 42 responden $(60,0 \%)$ sedangkan yang terendah sebanyak 28 responden $(40,0 \%)$

Self Regulated Learning 
Dapat diketahui bahwa disribusi frekuensi self regulated learning yang tinggi dalam kategori baik yaitu sebanyak 43 responden (61,4\%) sedangkan yang terendah dalam kategori kurang baik yaitu sebanyak 27 reponden $(38,6 \%)$.

Tingkat Stres

\begin{tabular}{crc}
\hline $\begin{array}{c}\text { Tingkat } \\
\text { Stres }\end{array}$ & $\begin{array}{c}\text { Jumlah } \\
\text { (n) }\end{array}$ & $\begin{array}{c}\text { Presentase } \\
\mathbf{( \% )}\end{array}$ \\
\hline Ringan & 31 & $44,3 \%$ \\
\hline Berat & 39 & $55,7 \%$ \\
\hline Jumlah & $\mathbf{7 0}$ & $\mathbf{1 0 0} \%$ \\
\hline
\end{tabular}

Dapat diketahui bahwa distribusi frekuensi tingkat stres yang tertinggi dalam kategori berat yaitu sebanyak

39 responden $(55,7 \%)$ sedangkan yang terendah dalam kategori ringan sebanyak 31 responden $(44,3 \%)$.

3. Analisis Bivariat

a. Uji Multikolinearitas

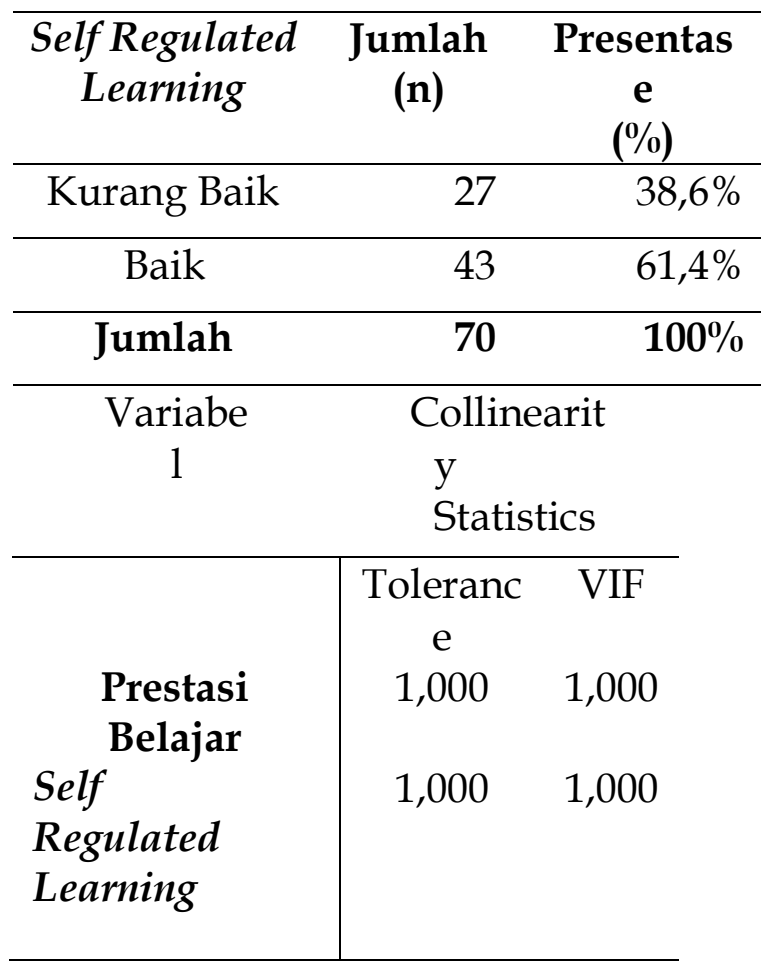

Berdasarkan data diatas dalam pengambilan keputusan dalam multikolinearitas dapat dengan melihat Tolerance dan VIF, hasil uji antar variabel independen menunjukan bahwa nilai Tolerance variabel prestasi belajar (X1) 1,000, dan self regulated learning (X2) 1,000 yakni lebih besar dari 0.10, sementara itu nilai VIF variabel prestasi belajar dan self regulated learning 
yaitu 1,000 yakni lebih kecil dari 10.00 sehingga dapat disimpulkan tidak terjadi multikolinearitas.

\section{Uji Heterokedastisitas}

\begin{tabular}{l|l}
\multicolumn{1}{c}{ Variabel } & \multicolumn{1}{c}{ Sig } \\
\hline Prestasi Belajar & 0,100 \\
\hline Self Regulated Learning & 0,733
\end{tabular}

Variabel prestasi belajar $\left(\mathrm{X}_{1}\right)$ sebesar $0.100>0.05$, yang artinya tidak terjadi heteroskedastisitas pada variabel $\left(\mathrm{X}_{1}\right)$, dan untuk self regulated learning (X2) sebesar $0.733>0.05$, yang artinya tidak terjadi heteroskedastisitas pada variabel $\left(\mathrm{X}_{2}\right)$.

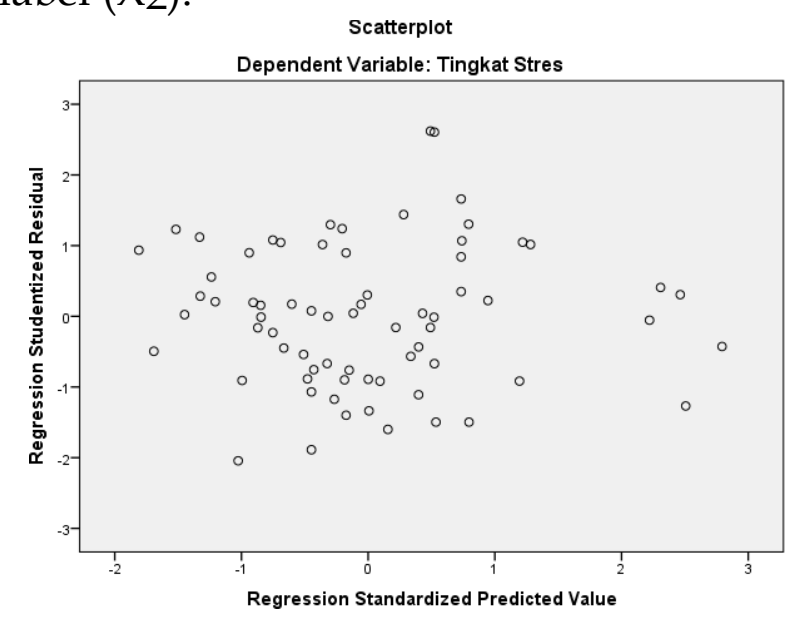

Berdasarkan grafik scatterplots terlihat ahwa titik-titik menyebar secara acak serta tersebar baik diatas maupun dibawah angka angka 0 pada sumbu Y. penyebaran titik-titik data tidak membentuk pola gelombang bergelombang melebar kemudian menyempit dan melebar kemabali. Jadi dapat disimpulkan bahwa tidak terjadi masalah heteroskedastisitas, sehingga model regresi yang baik dan ideal dapat terpenuhi.

\section{Uji Hipotesis}

a. Uji T (Parsial)

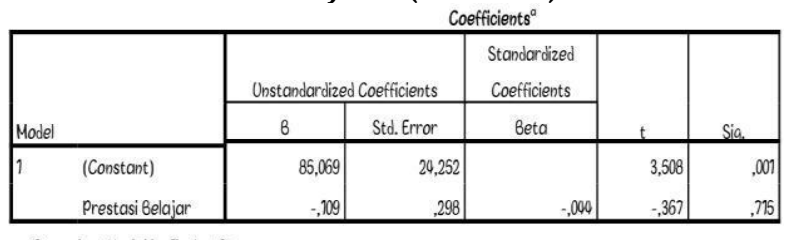

a. Oependent Variable: Tingkat Stres

Variabel prestasi belajar menunjukan hasil Thitung lebih kecil dari Ttabel yaitu sebesar $-0.367<1.294$ dengan taraf signifikan $10 \%$ yaitu $(0.10)$. sehingga dapat disimpulkan bahwa Ho diterima dan Ha ditolak artinya variabel prestasi belajar tidak berpengaruh terhadap tingkat stres siswa full day school. 


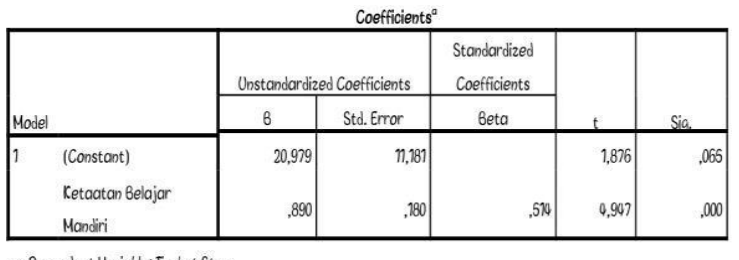

a. Oependent Variable: Tingkot Stres

Variabel self regulated learning menunjukan hasil Thitung lebih besar dari Ttabel yaitu sebesar $4.947>1.294$ dengan taraf signifikan 10\% yaitu (0.10). sehingga dapat disimpulkan bahwa Ho ditolak dan Ha diterima artinya variabel self regulated learning berpengaruh terhadap tingkat stres siswa full day school.

a. Uji F (Simultan)

ANOVA

\begin{tabular}{|c|c|c|c|c|c|c|}
\hline \multicolumn{2}{|c|}{ Model } & Sum of Scuares & $d f$ & Mean Square & $f$ & Sig. \\
\hline 1 & Regression & 928,982 & 2 & 464,497 & 12,190 &, $000^{b}$ \\
\hline & Residual & 2552,961 & 67 & 38,104 & & \\
\hline & Total & 3481,943 & 69 & & & \\
\hline
\end{tabular}

Bersadarkan tabel diatas diperoleh nilai Fhitung dan Ftabel dengan hasil 12.190 dengan taraf signifikansi 10\% (0.10) yaitu 2,38. maka hopotesis diterima dan terdapat pengaruh yang signifikan pada variabel prestasi belajar dan self regulated learning secara simultan berpengaruh terhadap tingkat stres siswa full day school.

\section{b. Uji Korelasi Berganda}

\section{Model Summary}

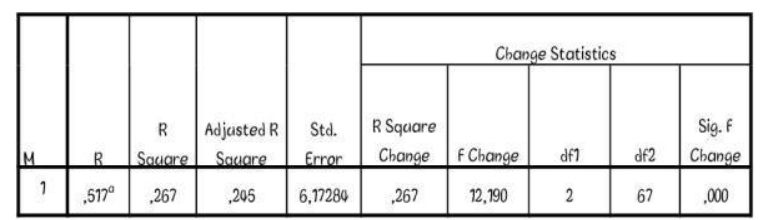

Berdasarkan tabel Model Summary bahwa besarnya pengaruh antara prestasi belajar (X1) dan self regulated learning (X2) terhadap tingkat stres siswa full day school (Secara Simultan) (Y) yang dihitung dengan koefisien korelasi ditunjukan dengan nilai $\mathrm{R}=0.517$. Hal ini menunjukan pengaruh yang sedang. Sedangkan kontribusi (R Square) variabel prestasi belajar dan self regulated learning adalah 0.267.

\section{KESIMPULAN}

Berdasarkan hasil penelitian dan pembahasan tentang pengaruh prestasi belajar dan self regulated learning terhadap tingkat stres siswa full day school di SMK Kesehatan Utama Insani Tahun 2020 dengan menggunakan uji F dapat disimpulkan bahwa ada pengaruh antara prestasi belajar dan self regulated learning terhadap tingkat stres siswa full day school. Dengan hasil nilai signifikansi $10 \%$ diaptkan hasil $12.190>2,38$.

\section{Saran}

1. Bagi Institusi STIKes Yatsi 
Hasil penelitan ini diharapkan dapat dimanfaatkan bagi instittusi pendidikan untk menambah referensi mahasiswa untuk belajar diperpustakaan dan dapat dikembangkan lagi oleh peneliti selanjutnya.

2. Bagi Peneliti Selanjutnya

Bagi peneliti selanjutnya diharapkan melakukan penelitian selanjutya dengan judul tingkat stres siswa sekolah sehari penuh (full day school) denagn usia dan tempat yang berbeda, dengan melibatkan dampak yang akan timbul dari tingkat stres siswa sekolah sehari penuh (full day school).

\section{E. DAFTAR PUSTAKA}

Alanshori, M. Z. (2016). Efektivitas pembelajraan full day school terhadap prestasi belajar siswa. 10(1).

Chahya Triana, D. (2019). Pengaruh Persepsi Siswa Terhadap Full Day School Pada Stres Akademik Siswa SMA Negri 1 Karanganom Klaten. 5(7).

Fasikhah, S. S., \& Fatimah, S. (2013). SELF-REGULATED LEARNING (SRL) DALAM MENINGKATKAN PRESTASI AKADEMIK PADA MAHASISWA. 01(01).

Fuentes, M. C., García-Ros, R., \& Pérez- González, F. (2019). Effects of Parenting Styles on Self-Regulated Learning and Academic Stress in Spanish Adolescents. $16,1-19$.

Haryu. (2013). Self regulated learning motivasi berprestasi \& prestasi belajar (1 ed.).

Juandi, A., \& Sontani, U. T. (2017). Keterampilan dan kreativitas mengajar guru sebagai determinan terhadap prestasi belajar siswa. 2(2), 242-250.

Kristiyani, titik. (2016). Self-regulated learning konsep, implikasi, dan tantangannya bagi siswa di indonesia. 